\title{
Parasites of the head of Scomber colias (Osteichthyes: Scombridae) from the western Mediterranean Sea
}

\section{Salvatore Mele ${ }^{1 *}$, Maria Grazia Pennino², Maria Cristina Piras ${ }^{1}$, José María Bellido², Giovanni Garippa ${ }^{1}$ and Paolo Merella ${ }^{1}$}

\author{
${ }^{1}$ Parassitologia e Malattie Parassitarie, Dipartimento di Medicina Veterinaria, Università di Sassari, via Vienna, 2, 07100, Sassari, Italy; \\ ${ }^{2}$ Instituto Español de Oceanografía, Centro Oceanográfico de Murcia, C/ Varadero, 1, Apdo. 22, 30740, San Pedro del Pinatar, Spain
}

\begin{abstract}
The metazoan parasite assemblage of the head of 30 specimens of the Atlantic chub mackerel (Scomber colias) from the western Mediterranean Sea was analysed. Eight species of parasites were found, four mazocraeid monogeneans: Grubea cochlear (prevalence $=10 \%)$, Kuhnia scombercolias (59\%), K. scombri (52\%), Pseudokuhnia minor (86\%); three didymozoid trematodes: Nematobothrium cf. faciale (21\%), N. filiforme (41\%), N. scombri (7\%); and one laerneopodid copepod: Clavelissa scombri (7\%). Results were compared with previously published data from 14 localities of the eastern Mediterranean Sea and the Atlantic Ocean, using non-parametric univariate and multivariate analyses, and the whole parasite fauna of $S$. colias was compared with that of the congeners (S. australasicus, S. japonicus and S. scombrus). Parasites showed to reflect the biogeographical and phylogenetic history of host. From a methodological point of view, the use of both non-parametric univariate and multivariate techniques proved to be effective tools to detect dissimilarities between parasite assemblages.
\end{abstract}

\section{Keywords}

Didymozoidae, Lernaeopodidae, Mazocraeidae, Scomber colias, Mediterranean Sea, Sardinia

The mackerels (Osteichthyes: Scombridae: Scomber spp.) include four species widely distributed in the Atlantic (Scomber colias Gmelin, 1789; Scomber scombrus Linnaeus, 1758) and Indo-Pacific (Scomber australasicus Cuvier, 1832; Scomber japonicus Houttuyn, 1782) Oceans (Catanese et al. 2010). Among them, S. colias is an epipelagic fish inhabiting the warm and temperate transition areas of the Atlantic Ocean and the Mediterranean Sea (Velasco et al. 2011). The fishery of this species is one of the most important in both the Atlantic Ocean and the Mediterranean Sea, with 237 thousand tons landed in 2009 (FAO 2011).

The parasite fauna of the species of the genus Scomber is composed of adult stages of helminths and copepods (Cressey and Cressey 1980; Gibson et al. 2005; Costa et al. 2007) specific to Scomber spp., which are mainly located in the head organs and tissues (Table I), and of larval stages of helminths (Oliva et al. 2008; Costa et al. 2011), infecting above all the viscera and body cavity.

The aim of this study is to describe the parasite fauna of the head of S. colias from the western Mediterranean Sea and to compare the results with data from the Atlantic Ocean and the Mediterranean Sea.

Parasites were collected from $30 \mathrm{~S}$. colias caught in the Gulf of Asinara (Sardinia, western Mediterranean Sea) in June 2009 by commercial fishing. After landing the fish were measured (range of total length $=23.5-37.0 \mathrm{~cm}$ ), weighed (range of total weight $=122-549 \mathrm{~g}$ ), and the heads excised, stored individually in plastic bags and frozen at $-20^{\circ} \mathrm{C}$.

Subsequently, the heads (including gills and heart) were defrosted and examined under a stereomicroscope for meta- 


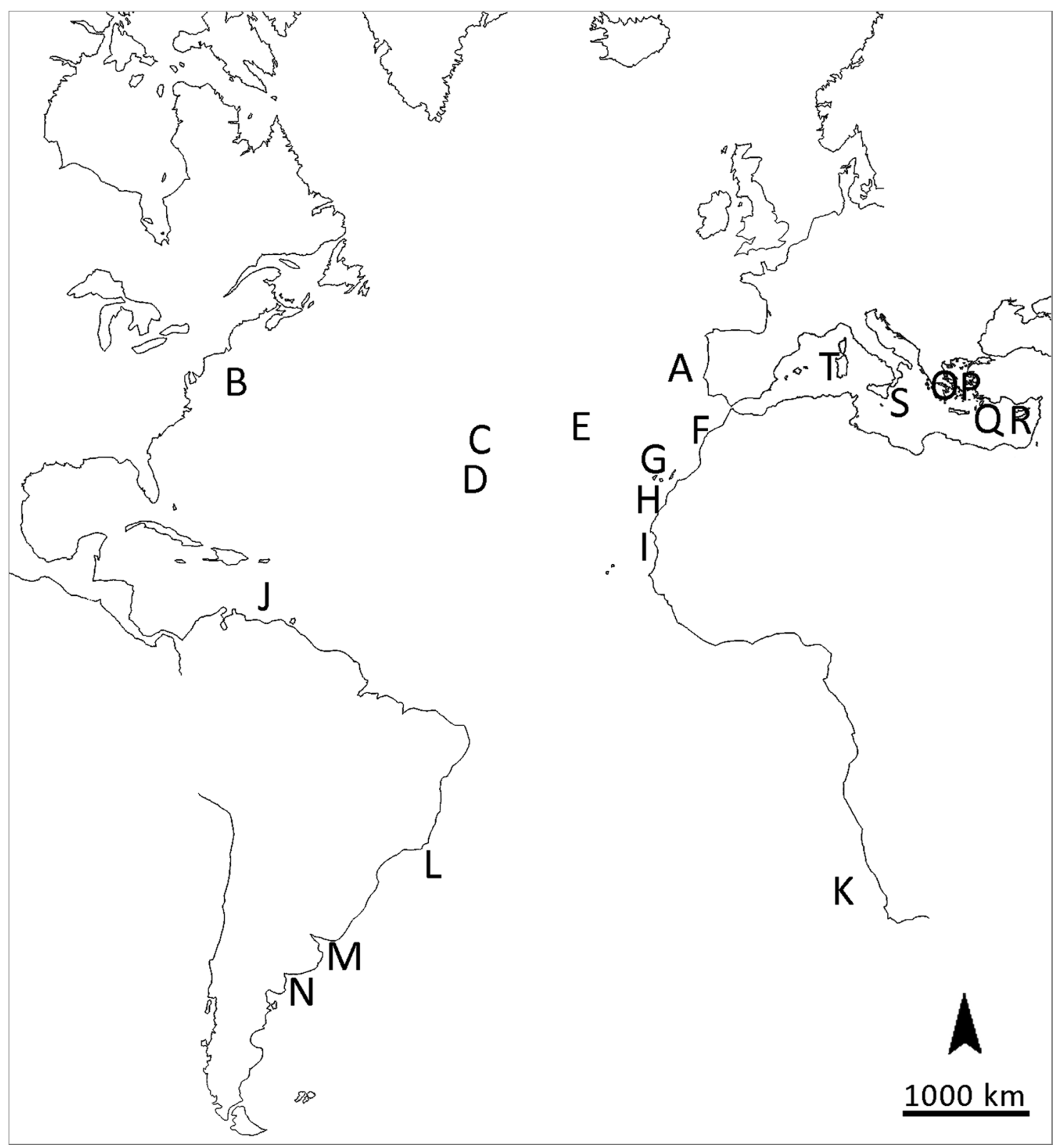

Fig. 1. Distribution of data published on the parasites of Scomber colias: A, North eastern Atlantic Ocean; B, North western Atlantic Ocean; C, Irving Bank; D, Great Meteor Bank; E, Madeira; F, North Morocco; G, Canaries; H, Western Sahara; I, Mauritania; J, central western Atlantic Ocean; K, South eastern Atlantic Ocean; L, Rio de Janeiro State; M, El Rincón; N, Mar de Plata; O, Aegean Sea (Area 1); P, Aegean Sea (Area 2); Q, Levantine Sea (Area 1); R, Levantine Sea (Area 2); S, central Mediterranean Sea; T, western Mediterranean Sea (present study)

zoan parasites. All parasites were counted and stored in $70 \%$ ethanol. Species identification was done by literature review and descriptive bibliography; for monogeneans: Rohde and Watson (1985) and Rohde (1989); for didymozoids: Baylis (1938) and Yamaguti (1970); for copepods: Cressey and Cressey (1980).

Prevalence, mean abundance and mean intensity of each parasite species were calculated according to Bush et al. (1997). The confidence interval of prevalence was calculated with the Sterne exact method, and the confidence intervals of the mean abundance and mean intensity were obtained by the bias-corrected and accelerated Efron-Tibshirani bootstrap (Reiczigel and Rózsa 2005).

The results were compared with those of 10 localities of the Atlantic Ocean (Cremonte and Sardella 1997; Alves et al. 2003; Shukhgalter 2004; Oliva et al. 2008; Costa et al. 2011) (Fig. 1, Table II), using both univariate and multivariate analyses. Because prevalence was the index reported in all papers, it was chosen for assessing the differences between pairs of localities with the Fisher exact test, (Reiczigel and Rozsa 
2005). Accidental species (i.e. only one specimen was collected) were not included in the analyses. Multivariate analyses were carried out only on parasite species with a significant difference in prevalence between at least one pair of localities. Two dimensional non-metric multidimensional scaling (NMDS, "Jaccard" distance, "monoMDS" engine, meta MDS" function, "vegan" library of the R-software, R Development Core Team 2012) and hierarchical cluster analysis (CA, "average" method, "hclust" function, "stats" library of the R-software, R Development Core Team 2012) were performed on a Ruzicka (Jaccard) similarity matrix to identify possible differences between the localities examined (Oksanen 2011). The vectors of each variable were included in NMDS graphs in order to determine the principal factors driving the separation of the areas. The significance of the values of the vectors was evaluated ( $p$-value $\leq 0.05$, "envfit" function, "vegan" library of the R-software, R Development Core Team 2012). To estimate the goodness of fit of the NMDS graphs and how the hierarchical structure of the CA represented the effective distance between the parasite assemblages, the Kruskal stress (Stress, "goodness" function, "vegan" library of the R-software, R Development Core Team 2012) and the coefficient of cophenetic correlation (Rc, "cophenetic" function, "stats" library of the R-software, R Development Core Team 2012) were computed.

The community dissimilarity of helminths was evaluated with the Marczewski-Steinhaus distance (MS, "cc" method, "betadiver" function, "vegan" library of the R-software, R Development Core Team 2012), and the Bray-Curtis index (BC, "-1" method, "betadiver" function, "vegan" library of the R-software, R Development Core Team 2012) functions.

Table I. Published data on the parasites of the head of the genus Scomber according to species: $\mathrm{Sa}$, S. australasicus, Sc, S. colias, Sj, S. japonicus, Ss, S. scombrus. Data from: 1, Baylis (1938); 2, Ichihara et al. (1968); 3, Yamaguti (1970); 4, Kabata (1979); 5, Cressey and Cressey (1980); 7, Gibson et al. (1981); 8, Rohde (1989); 9, Somdal and Schram (1992); 10, Hayward et al. (1998); 11, Amirzha (2003); 12, Shukhgalter (2004); 13, Oliva et al. (2008)

\begin{tabular}{|c|c|c|c|c|}
\hline & $\mathbf{S a}$ & Sc & $\mathbf{S j}$ & Ss \\
\hline \multicolumn{5}{|l|}{ Monogenea Mazocraeidae } \\
\hline Grubea australis Rohde, 1987 & 10 & & & \\
\hline Grubea cochlear Diesing, 1858 & & 13 & & 9 \\
\hline Kuhnia scombercolias Nasir et Fuentes Zambrano, 1983 & 10 & 13 & 8 & \\
\hline Kuhnia scombri (Kuhn, 1829) & 10 & 13 & 8 & 9 \\
\hline Kuhnia sprostonae Price, 1961 & 10 & 8 & 16 & 9 \\
\hline Pseudokuhnia minor (Goto, 1984) & 10 & 13 & 8 & \\
\hline \multicolumn{5}{|l|}{ Trematoda Didymozoidae } \\
\hline Didymozoon longicolle Ishii, 1935 & & & 2 & \\
\hline Halvorsenius exilis Gibson, MacKenzie et Cottle (1981) & & 13 & & 7 \\
\hline Nematobothrium faciale (Baylis, 1938) & & & & 1 \\
\hline Nematobothrium filiforme Yamaguti, 1934 \$ & & 12 & 2 & \\
\hline Nematobothrium scombri (Taschenberg, 1879) \# & & 13 & 3 & 1 \\
\hline \multicolumn{5}{|l|}{ Crustacea Copepoda } \\
\hline Brachiella magna Kabata, 1968 & 10 & & & \\
\hline Caligus sp. & 10 & & & \\
\hline Caligus diaphanus von Nordmann, 1832 & & & & 4 \\
\hline Caligus pelamydis Krøyer, 1863 & & 7 & 4 & 9 \\
\hline Clavellisa scombri (Kurz, 1877) & 5 & 13 & 5 & 9 \\
\hline Clavellopsis saba Yamaguti, 1939 & & & 2 & \\
\hline Hatschekia sp. & & 11 & & \\
\hline Kabatazus paradoxus (Kabata, 1979) & & & & 9 \\
\hline Laernea sp. & & 11 & & \\
\hline Pumiliopes jonesi (Bennet, 1968) & 5 & 5 & 5 & \\
\hline \multicolumn{5}{|l|}{ Crustacea Isopoda } \\
\hline Ceratothoa imbricata (Fabricius, 1775) & 10 & & & \\
\hline
\end{tabular}

\$, Nemathobothrium filiforme is considered as Didymozoidae gen. sp. sensu Shukhgalter (2004) and Nemathobothrium sp. sensu Costa et al. (2011)

\#, Nematobothrium scombri is considered as Nematobothrium spp. sensu Cremonte and Sardella (1997) 


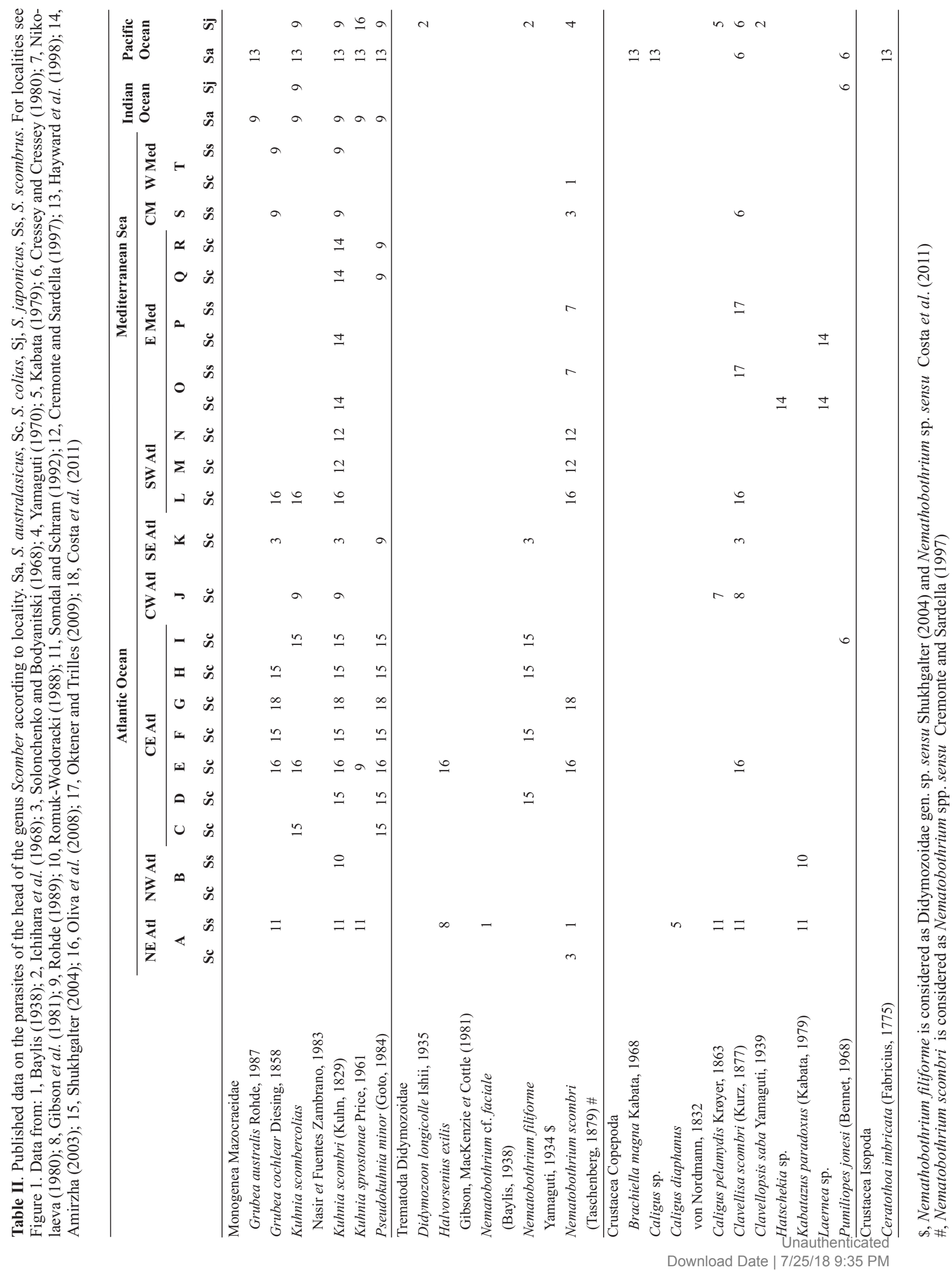


Eight species of parasites were found in the head of the 30 specimens of S. colias examined (Table II): Grubea cochlear Diesing, 1858, Kuhnia scombercolias Nasir et Fuentes Zambrano, 1983, K. scombri (Kuhn, 1829), Pseudokuhnia minor (Goto, 1894), Nematobothrium cf. faciale (Baylis, 1938), N. filiforme Yamaguti, 1934, N. scombri (Taschenberg, 1879), and Clavellisa scombri (Kurz, 1877).

Scomber colias is a new host record for $N$. cf. faciale, and the records of $K$. scombercolias, $N$. cf. faciale, $N$. filiforme and $P$. minor extend the geographical range of these species to the western Mediterranean Sea. The prevalence, mean abundance and mean intensity of infection of the parasites found in $\mathrm{S}$. colias are shown in Table III. Pseudokuhnia minor had the highest prevalence $(86 \%)$, mean abundance (5.4) and mean intensity (6.3), and it was the dominant species.

Comparing present and published data (Table IV), each parasite species showed significant differences of prevalence between at least one pair of localities, and some had higher prevalence in one locality than in all others, particularly: $K$. scombri, $P$. minor, $N$. cf. faciale and $N$. filiforme in the western Mediterranean Sea (T, present data); Laernea sp. sensu Akmirza, 2003 in the eastern Mediterranean Sea (O-P); G. cochlear and N. scombri in the Brazilian area (L); C. scombri and P. minor at Madeira (E).

The grouping of the areas in the NMDS plot of the Mazocraeidae (Fig. 2) is driven by significant prevalence values of the four species considered ( $\mathrm{p}$-value $<0.05$ ). The analysis of this plot according to the 1 axis showed that, apart from the Great Meteor Bank (D) of the central eastern Atlantic Ocean, the prevalence of $P$. minor distinguishes the central eastern Atlantic areas (C, E-I) and the western Mediterranean Sea (T) from all the other localities; whereas according to the 2 axis the prevalences of G. cochlear, K. scombercolias and K. scombri separate the Brazilian area (L) from almost all of the other areas, except for the Aegean Sea area (O).

The CA dendrogram of the prevalence of Mazocraeidae (Fig. 2) showed three different groups: the Brazilian one
(L); the sub-group of the Argentine areas of the South western Atlantic Ocean (M-N) and the sub-group of three areas of the eastern Mediterranean Sea (P-R); and the Aegean area of the eastern Mediterranean Sea (D), the Great Meteor Bank of the central Atlantic Ocean (O), and the subgroup of all the other central Atlantic and the western Mediterranean areas $(\mathrm{T})$.

The separation of the cluster of the western Mediterranean and the central eastern Atlantic samples, and the cluster of the eastern Mediterranean (apart from the Aegean Sea) and the Argentine assemblages $(\mathrm{M}-\mathrm{N})$ is related to the low prevalence of $K$. scombri and the absence of other mazocraeids in the eastern Mediterranean and Argentine Seas (Rohde 1989; Cremonte and Sardella 1997; Akmirza 2003), explaining why the most distant and oceanographically different areas of the entire range of $S$. colias cluster together. Apart from K. scombri, that was distributed throughout the geographical range of $S$. colias, the other monogeneans are limited to specific areas of the host distribution. For example, $K$. sprostonae has been reported from Madeira (Oliva et al. 2008), and P. minor from the South and central eastern Atlantic Ocean and the western Mediterranean Sea, meaning that (i) these parasites do not find suitable condition to live outside these areas, and that (ii) they can leave their host when it migrates outside of the endemic area of these parasites. This fact suggests that the distance between the opposite coasts of the Atlantic Ocean could be a barrier to the spread of these parasites of $S$. colias, as analogously indicated by Rohde and Hayward (2000) for the monogeneans of two scombrids with amphi-Pacific distribution (Scomberomorus spp. and Grammatorcynus spp.). Concerning the differences in the ectoparasite fauna of $S$. colias from the eastern and western Mediterranean Seas, they can be due to the different oceanographic conditions of the shallow water of these basins (Robinson et al. 2001) as it has also been reported for other fish (Marzoug et al. 2012; Culurgioni et al. 2014).

Table III. List of the parasites found in the head of Scomber colias from the western Mediterranean Sea, with indication of prevalence (P\%), mean abundance $(\mathrm{mA})$, and mean intensity of infection $(\mathrm{mI}) .95 \%$ confidence intervals in brackets

\begin{tabular}{|c|c|c|c|}
\hline Parasites & $\mathbf{P} \%$ & $\mathbf{m A}$ & mI \\
\hline \multicolumn{4}{|l|}{ Monogenea Mazocraeidae } \\
\hline Grubea cochlear Diesing, 1858 & $10(3-27)$ & $0.1(0.0-0.2)$ & $1.0(-)$ \\
\hline Kuhnia scombri (Kuhn, 1829) & $52(34-69)$ & $1.4(0.9-2.1)$ & $2.7(2.1-3.7)$ \\
\hline Pseudokuhnia minor (Goto, 1984) & $86(69-95)$ & $5.4(3.9-7.1)$ & $6.3(4.8-7.9)$ \\
\hline Nematobothrium filiforme Yamaguti, 1934 & $21(9-40)$ & $0.5(0.1-1.1)$ & $2.2(1.2-4.0)$ \\
\hline Nematobothrium scombri (Taschenberg, 1879) & $7(1-22)$ & $0.1(0.0-0.2)$ & $1.0(-)$ \\
\hline \multicolumn{4}{|l|}{ Crustacea Copepoda } \\
\hline Clavellisa scombri (Kurz, 1877) & $7(1-22)$ & $0.1(0.0-0.2)$ & $1.0(-)$ \\
\hline
\end{tabular}


Table IV. Comparison of the prevalence of the helminths of the head of Scomber colias from the Atlantic Ocean and the Mediterranean Sea. *, significant difference $(p \leq 0.05)$; -, no data. For localities see Fig. 1

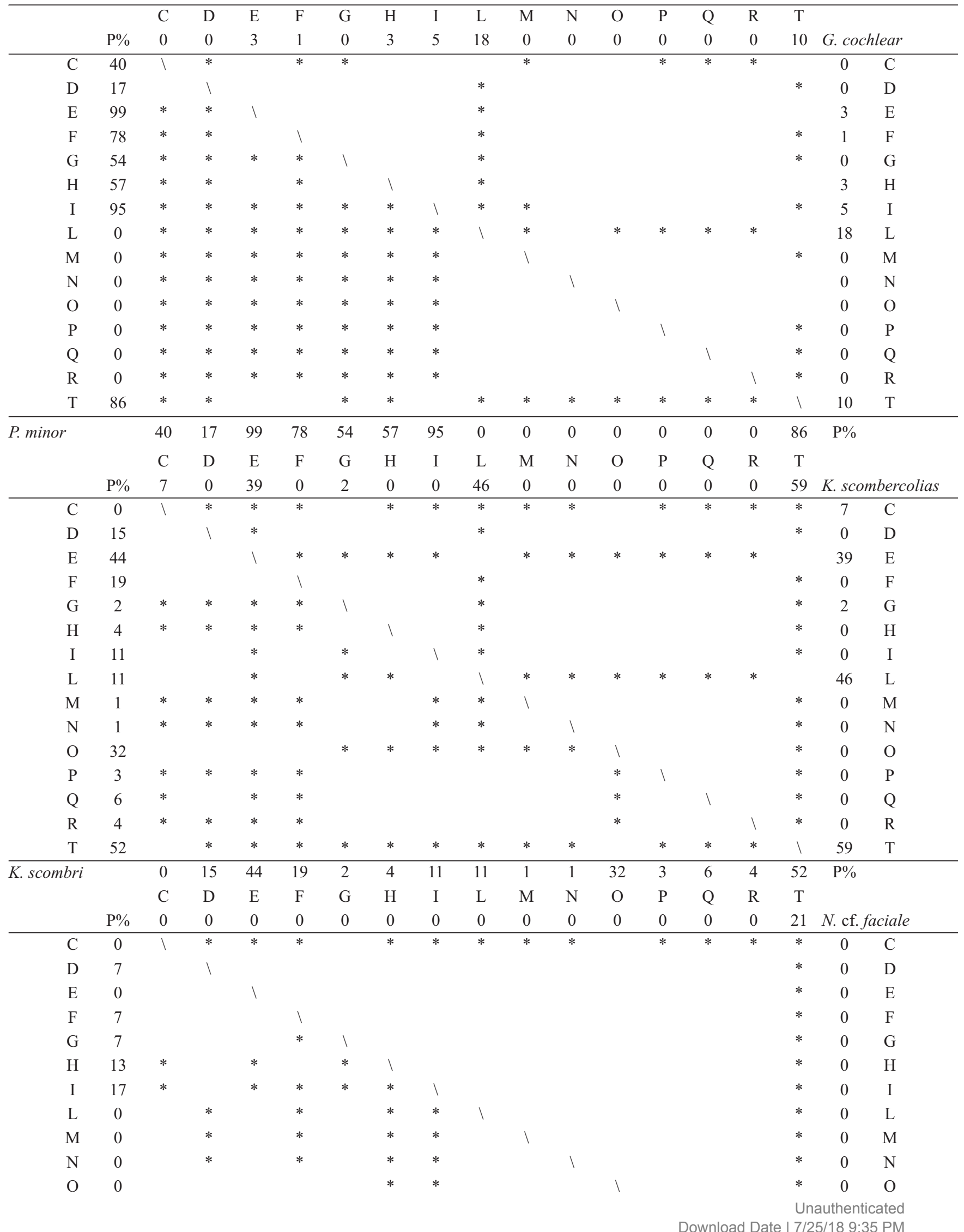




\begin{tabular}{|c|c|c|c|c|c|c|c|c|c|c|c|c|c|c|c|c|c|c|}
\hline $\mathrm{P}$ & 0 & & & & $*$ & & $*$ & $*$ & & & & & 1 & & & $*$ & 0 & $\mathrm{P}$ \\
\hline $\mathrm{Q}$ & 0 & & & & & & $*$ & $*$ & & & & & & 1 & & $*$ & 0 & $\mathrm{Q}$ \\
\hline $\mathrm{R}$ & 0 & & $*$ & & * & & $*$ & $*$ & & & & & & & 1 & $*$ & 0 & $\mathrm{R}$ \\
\hline $\mathrm{T}$ & 41 & $*$ & * & $*$ & * & $*$ & $*$ & $*$ & $*$ & $*$ & $*$ & & & & & 1 & 21 & $\mathrm{~T}$ \\
\hline $\bar{N}$. filiforme & & 0 & 7 & 0 & 7 & 7 & 13 & 17 & 0 & 0 & 0 & 0 & 0 & 0 & 0 & 41 & $\mathrm{P} \%$ & \\
\hline & & $\mathrm{C}$ & $\mathrm{D}$ & $\mathrm{E}$ & $\mathrm{F}$ & $\mathrm{G}$ & $\mathrm{H}$ & I & $\mathrm{L}$ & $\mathrm{M}$ & $\mathrm{N}$ & $\mathrm{O}$ & $\mathrm{P}$ & $\mathrm{Q}$ & $\mathrm{R}$ & $\mathrm{T}$ & & \\
\hline & $\mathrm{P} \%$ & 0 & 0 & 28 & 0 & 2 & 0 & 0 & 55 & 9 & 7 & 0 & 0 & 0 & 0 & 7 & N. scom & \\
\hline $\mathrm{C}$ & 0 & 1 & & $*$ & & & & & $*$ & & & $*$ & & & & & 0 & $\mathrm{C}$ \\
\hline D & 0 & & 1 & * & & & & & * & $*$ & & * & & & & & 0 & $\mathrm{D}$ \\
\hline $\mathrm{E}$ & 7 & & & 1 & * & $*$ & $*$ & $*$ & $*$ & $*$ & $*$ & & $*$ & * & * & * & 28 & E \\
\hline $\mathrm{F}$ & 0 & & & $*$ & 1 & $*$ & & & $*$ & $*$ & $*$ & $*$ & & & $*$ & * & 0 & $\mathrm{~F}$ \\
\hline $\mathrm{G}$ & 0 & & & $*$ & & 1 & $*$ & $*$ & $*$ & & & $*$ & & & & & 2 & $\mathrm{G}$ \\
\hline $\mathrm{H}$ & 0 & & & * & & & 1 & & $*$ & $*$ & $*$ & $*$ & * & & * & * & 0 & $\mathrm{H}$ \\
\hline I & 0 & & & * & & & & 1 & $*$ & $*$ & * & $*$ & & & & & 0 & I \\
\hline $\mathrm{L}$ & 0 & & & $*$ & & & & & 1 & $*$ & $*$ & $*$ & $*$ & $*$ & $*$ & * & 55 & $\mathrm{~L}$ \\
\hline $\mathrm{M}$ & 0 & & & $*$ & & & & & & 1 & & $*$ & & & & & 9 & $\mathrm{M}$ \\
\hline $\mathrm{N}$ & 0 & & & $*$ & & & & & & & 1 & $*$ & & & & & 7 & $\mathrm{~N}$ \\
\hline $\mathrm{O}$ & 0 & & & & & & & & & & & 1 & $*$ & * & $*$ & & 0 & $\mathrm{O}$ \\
\hline $\mathrm{P}$ & 0 & & & $*$ & & & & & & & & & 1 & & & & 0 & $\mathrm{P}$ \\
\hline $\mathrm{Q}$ & 0 & & & & & & & & & & & & & 1 & & & 0 & $\mathrm{Q}$ \\
\hline $\mathrm{R}$ & 0 & & & $*$ & & & & & & & & & & & 1 & & 0 & $\mathrm{R}$ \\
\hline $\mathrm{T}$ & 0 & & & & & & & & & & & & & & & 1 & 7 & $\mathrm{~T}$ \\
\hline
\end{tabular}

\begin{tabular}{ccccccccccccccccccc}
\hline H. exilis & & 0 & 0 & 7 & 0 & 0 & 0 & 0 & 0 & 0 & 0 & 0 & 0 & 0 & 0 & 0 & $\mathrm{P} \%$ & \\
& & $\mathrm{C}$ & $\mathrm{D}$ & $\mathrm{E}$ & $\mathrm{F}$ & $\mathrm{G}$ & $\mathrm{H}$ & $\mathrm{I}$ & $\mathrm{L}$ & $\mathrm{M}$ & $\mathrm{N}$ & $\mathrm{O}$ & $\mathrm{P}$ & $\mathrm{Q}$ & $\mathrm{R}$ & $\mathrm{T}$ & & \\
& $\mathrm{P} \%$ & - & - & 8 & - & 0 & - & - & 2 & 0 & 0 & 0 & 0 & 0 & 0 & 7 & C. scombri \\
\hline $\mathrm{C}$ & - & $\backslash$ & - & - & - & - & - & - & - & - & - & - & - & - & - & - & $\mathrm{N} / \mathrm{D}$ & $\mathrm{C}$ \\
$\mathrm{D}$ & - & - & $\backslash$ & - & - & - & - & - & - & - & - & - & - & - & - & - & $\mathrm{N} / \mathrm{D}$ & $\mathrm{D}$ \\
$\mathrm{E}$ & 0 & & & $\backslash$ & - & $*$ & - & - & $*$ & $*$ & $*$ & & $*$ & & $*$ & & 8 & $\mathrm{E}$ \\
$\mathrm{F}$ & - & - & - & - & $\backslash$ & - & - & - & - & - & - & - & - & - & - & - & $\mathrm{N} / \mathrm{D}$ & $\mathrm{F}$ \\
$\mathrm{G}$ & 0 & & & & & $\backslash$ & & & & & & & & & & & 0 & $\mathrm{G}$ \\
$\mathrm{H}$ & - & - & - & - & - & - & - & - & - & - & - & - & - & - & - & - & $\mathrm{N} / \mathrm{D}$ & $\mathrm{H}$ \\
$\mathrm{I}$ & - & - & - & - & - & - & - & $\backslash$ & - & - & - & - & - & - & - & - & $\mathrm{N} / \mathrm{D}$ & $\mathrm{I}$ \\
$\mathrm{L}$ & 0 & - & - & & - & & - & - & $\backslash$ & & & & & & & 2 & $\mathrm{~L}$ \\
$\mathrm{M}$ & 0 & - & - & & - & & - & - & & $\backslash$ & & & & & & 0 & $\mathrm{M}$ \\
$\mathrm{N}$ & 0 & - & - & & - & & - & - & & & $\backslash$ & & & & & 0 & $\mathrm{~N}$ \\
$\mathrm{O}$ & 9 & - & - & & - & $*$ & - & - & $*$ & $*$ & $*$ & $\backslash$ & & & & 0 & $\mathrm{O}$ \\
$\mathrm{P}$ & 18 & - & - & $*$ & - & & - & - & $*$ & $*$ & $*$ & & $\backslash$ & & & 0 & $\mathrm{P}$ \\
$\mathrm{Q}$ & 0 & - & - & & - & & - & - & & & & $*$ & $*$ & $\backslash$ & & 0 & $\mathrm{Q}$ \\
$\mathrm{R}$ & 0 & - & - & & - & & - & - & & & & $*$ & $*$ & & $\backslash$ & 0 & $\mathrm{R}$ \\
$\mathrm{T}$ & 0 & - & - & & - & & - & - & & & & & $*$ & & & $\backslash$ & 7 & $\mathrm{~T}$ \\
\hline Lernaea $\mathrm{sp}$ & & - & - & 0 & - & 0 & - & - & 0 & 0 & 0 & 9 & 18 & 0 & 0 & 0 & $\mathrm{P} \%$ & \\
& & $\mathrm{C}$ & $\mathrm{D}$ & $\mathrm{E}$ & $\mathrm{F}$ & $\mathrm{G}$ & $\mathrm{H}$ & $\mathrm{I}$ & $\mathrm{L}$ & $\mathrm{M}$ & $\mathrm{N}$ & $\mathrm{O}$ & $\mathrm{P}$ & $\mathrm{Q}$ & $\mathrm{R}$ & $\mathrm{T}$ & & \\
\hline
\end{tabular}

The multivariate analysis of didymozoids (Fig. 2) did not include the eastern Mediterranean Sea and the central eastern Atlantic Ocean areas (C) because this family has not been described in these areas. The grouping of the areas in the NMDS plot of Didymozoidae is driven by the significant prevalence values of three species ( $N$. cf. faciale, $N$. filiforme and $N$. scombri). The analysis of this plot according to the 1 axis showed that the higher prevalence of $N$. cf. faciale and $N$. filiforme in the western Mediterranean Sea (T) and of
$N$. scombri in the Brazilian area (L) than in all the other localities, distinguish the didymozoid assemblages of these localities.

The CA of the prevalence of Didymozoidae (Fig. 2) identified four groups: the Brazilian and Madeira areas (L and E), the Argentine areas of the South western Atlantic Ocean ( $\mathrm{M}$ and $\mathrm{N}$ ), the western Mediterranean area $(\mathrm{T})$, and the other areas of the central eastern Atlantic Ocean (D, F-I). Apart from $N$. scombri, that has been found in all the geographical range 
of S. colias, except in the eastern Mediterranean Sea, the other didymozoids are limited to specific areas of the host distribution. For example, Halvorsenius exilis has been reported from Madeira (Oliva et al. 2008), $N$. cf. faciale from the western Mediterranean Sea, and N. filiforme from the South and central eastern Atlantic Ocean and the western Mediterranean Sea, meaning that: (i) these parasites seem not to find suitable environmental conditions and/or intermediate hosts outside of these areas; (ii) their intermediate hosts could be associated to the specific oceanographic conditions of the western Mediterranean Sea and eastern Atlantic Ocean; and (iii) the specimens of $S$. colias infected by these didymozoids do not migrate to the eastern Mediterranean Sea and the South western Atlantic
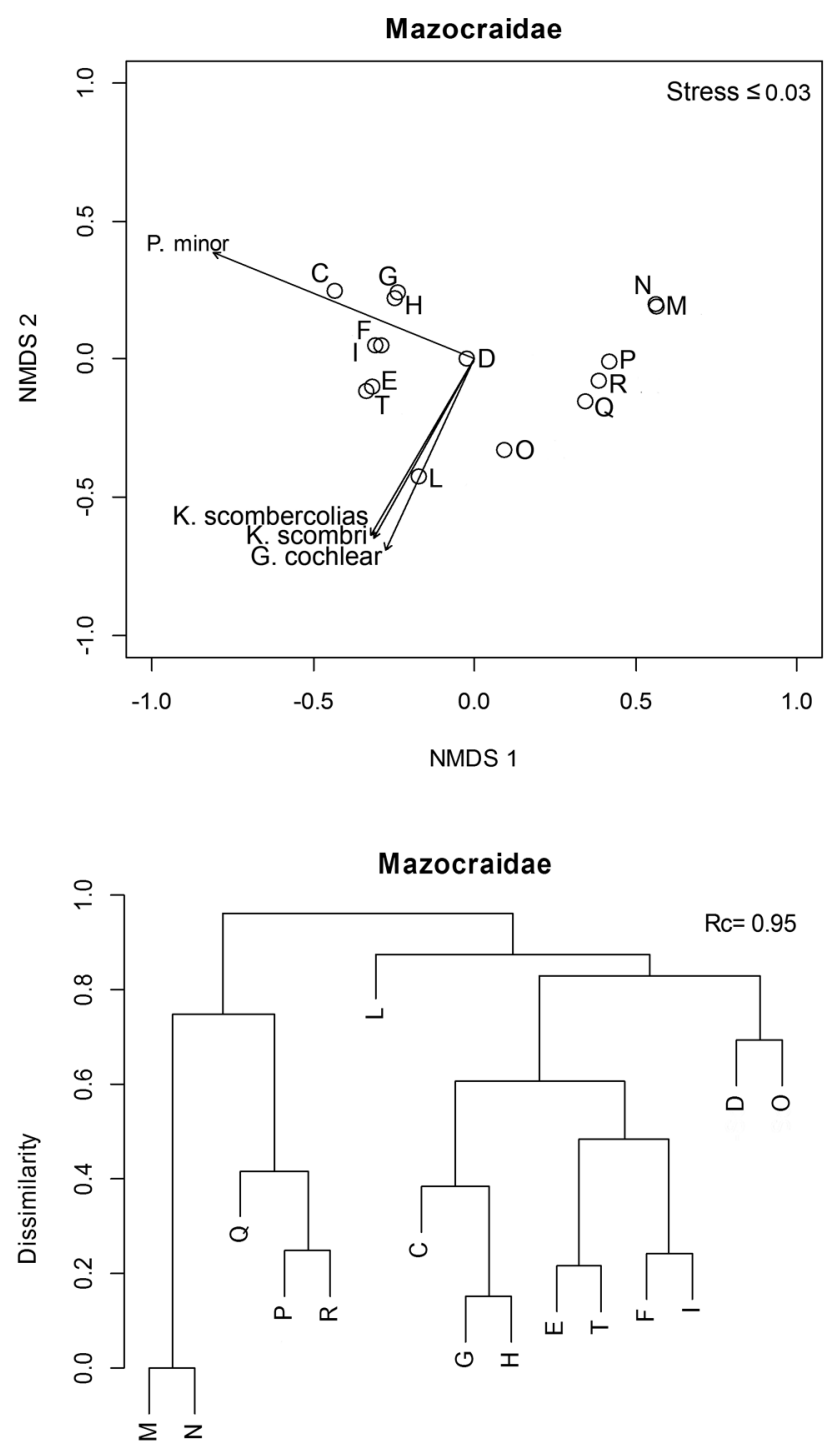

Locality
Ocean. In fact, several didymozoids have been recorded outside their endemic areas (Lester et al. 1985; Mele et al. 2012), because they cannot leave their hosts, being encysted in the host tissues (Pascual et al. 2006). The distance could be a barrier to the spread of these didymozoids between the opposite coasts of the Atlantic Ocean, as also showed for several mazocraeids (K. sprostonae, $P$. minor); whereas the different oceanographic conditions between the eastern and western Mediterranean Seas (Robison et al. 2001; Manca et al. 2004), which can support a different macro fauna (Garibaldi 1998), can be an important factor that could explain the different trematode faunas of these basins (Gargouri Ben Abdalah et al. 2010; Culurgioni et al. 2014).
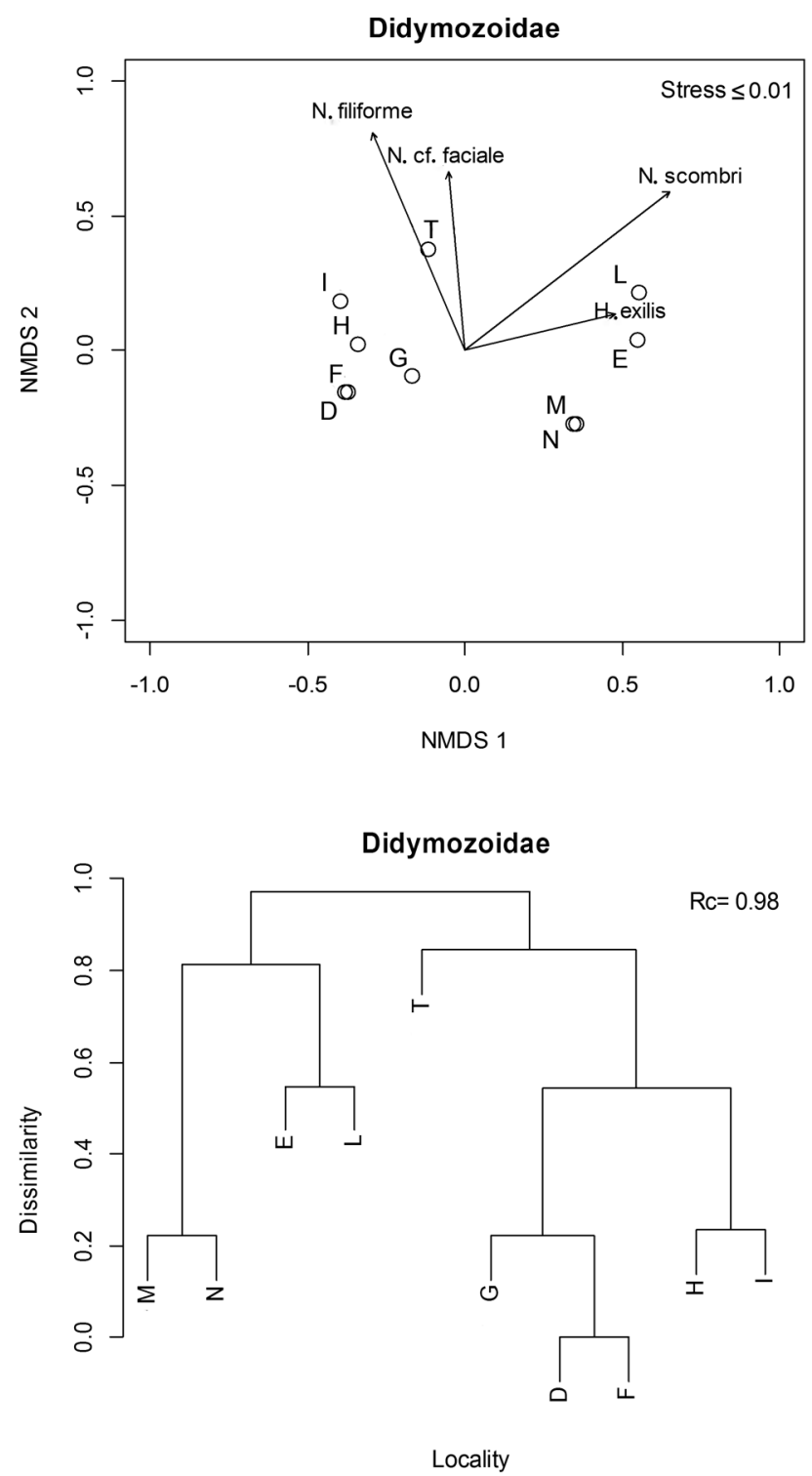

Fig. 2. Non-metric multidimensional scaling plots and cluster dendrograms based on the Ruzicka distance of the prevalence of the helminths of the head of Scomber colias that showed differences between at least one pairwise of localities, according to parasite family (Didymozoidae, Mazocraeidae). Stress values for the NMDS analyses were lower than 0.03 (0.00-0.01 for Didymozoidae and 0.01-0.03 for Mazocraidae), indicating that this analysis has sufficient resolution for reliable interpretation. For localities see Fig. 1 

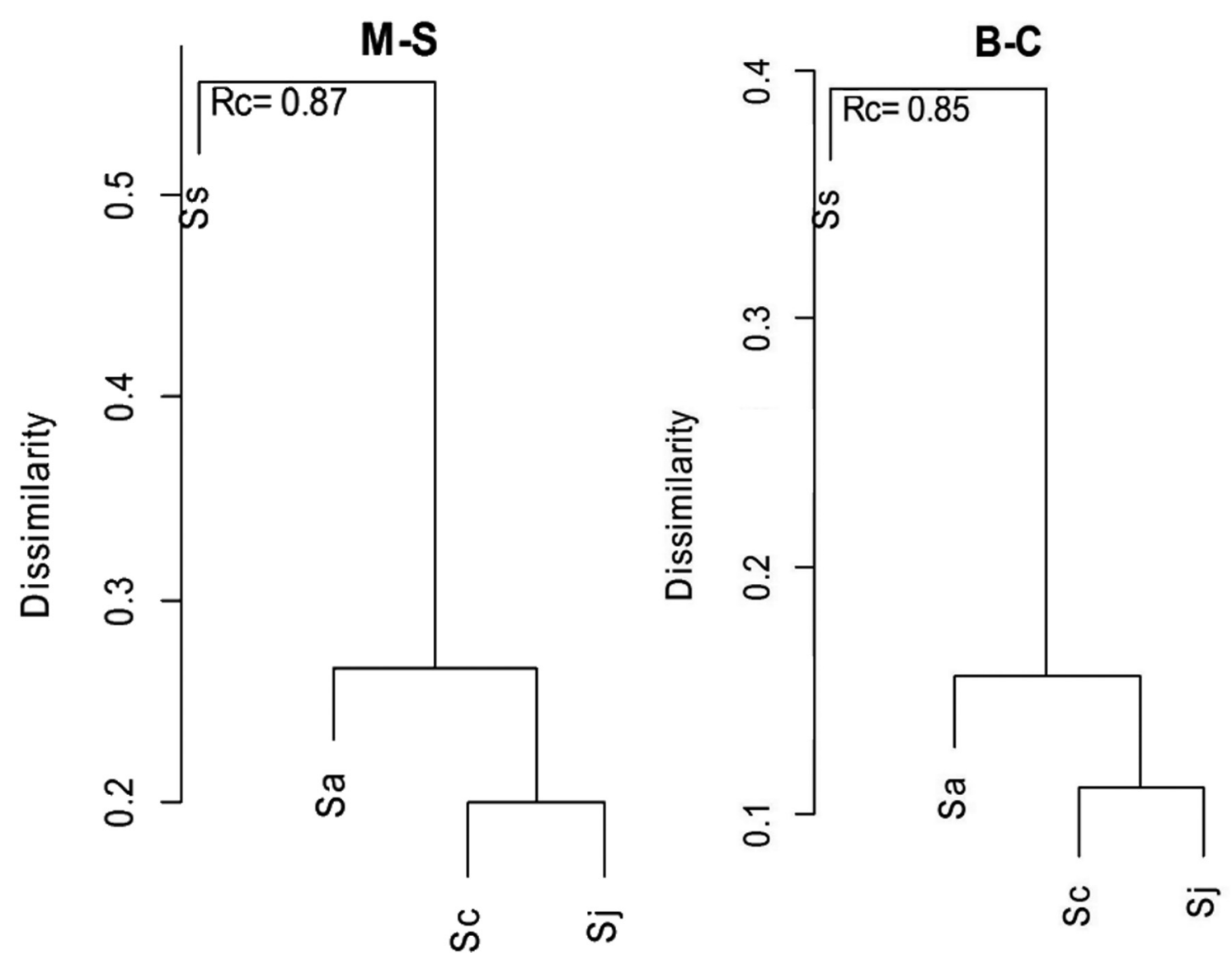

Fig. 3. Cluster dendrograms (group-average linkage) of the parasites of the head of the four species of the genus Scomber, S. australasicus (Sa), S. colias (Sc), S. japonicus (Sj) and S. scombrus (Ss), using Marczewski-Steinhaus (M-S) and Bray-Curtis (B-C) dissimilarity measures based on the presence/absence of parasites (see Tables I-III)

On the bases of the published and present data on the parasites of the head of the four species of the genus Scomber worldwide, a datasheet of presence/absence of parasites by geographical region was created (Tables I-III), making it possible to evaluate the dissimilarity between the parasite faunas of the four mackerel species (Fig. 3). Only mazocraeids were included in the statistical analysis because didymozoids of $S$. australasicus have not been identified to species level (Perera 1994). The parasite assemblage of $S$. colias and $S$. japonicus cluster together and they are well separated from those of $S$. australasicus and S. scombrus. Scomber colias shares $K$. scombri and K. sprostonae with all the other representatives of the genus Scomber, P. minor only with the IndoPacific S. australasicus and S. japonicus, and G. cochlear only with the Atlanto-Mediterranean S. scombrus. Among didymozoids, $S$. colias shares $N$. scombri with the other members of the genus Scomber, except S. australasicus, in which no didymozoids have been identified (Perera 1994); N. filiforme with $S$. japonicus; and $H$. exilis and $N$. cf. faciale with $S$. scombrus. The occurrence of a parasite species in two host species could be due to host switching from one to another host species which share the habitat, or to inheritance from a com- mon ancestor (Verneau et al. 2009). According to the cophylogenetic studies of Verneau et al. (2009), the current overlap of distributions of $S$. colias and S. scombrus in the AtlantoMediterranean area may allow the sharing of parasites between these hosts (i.e. G. cochlear and N. cf. faciale). On the other hand, the sharing of parasites among $S$. colias and the Indo-Pacific S. australasicus and S. japonicus cannot be explained by the current geographical distribution of the species, and it should have taken place in the past, before the segregation of hosts. For instance, K. sprostonae and K. scombri, parasites that infect all the species of the genus Scomber, could have been parasites of an ancestral host distributed worldwide, whose populations diverged after the emergence of geographical barriers (Cheng et al. 2011); in accordance with the evolutionary history proposed by these authors, the speciation of $K$. scombercolias, P. minor and N. filiforme may have occurred after the segregation of S. scombrus, due to the closure of the Tethys Sea, but before the divergence of S. colias and S. japonicus. On the other hand, the speciation of G. cochlear in the Atlantic Scomber spp. and of G. australis in the Indo-Pacific Scomber spp. may have occurred after the complete separation of the host populations. The cluster analysis of the 
mazocraeids of the four Scomber spp. seems to match with the phylogenetic relationships of the species of the genus Scomber (Cheng et al. 2011), suggesting that the speciation of parasites and hosts are closely related.

Acknowledgments. Research supported by the Spanish Government project PARATUN AGL2010-20892 and the Master and Back 20122013 project of the Regione Autonoma della Sardegna.

\section{References}

Akmirza A. 2003. Distribution of parasite fauna of chub mackerel in Aegean and Mediterranean Sea. Turkish Journal of Marine Sciences, 9, 187-195.

Alves D.R., Luque J.L., Abdallah. V.D. 2003. Metazoan parasites of chub mackerel, Scomber japonicus (Osteichthyes: Scombridae), from the coastal zone of the State of Rio de Janeiro, Brazil. Brazilian Journal of Veterinary Parasitology, 12, 164 170.

Baylis H.A. 1938. On two species of the trematode genus Didymozoon from the mackerel. Journal of the Marine Biological Association of the United Kingdom, 22, 485-492.

Bush A.O., Lafferty K.D., Lotz J.M., Shostak A.W. 1997. Parasitology meets ecology on its own terms: Margolis et al. revisited. Journal of Parasitology, 83, 575-583. DOI: 10.2307/3284 227.

Catanese G., Manchado M., Infante C. 2010. Evolutionary relatedness of mackerels of the genus Scomber based on complete mitochondrial genomes: strong support to the recognition of Atlantic Scomber colias and Pacific Scomber japonicus as distinct species. Gene, 452, 35-43. DOI: 10.1016/j.gene.2009. 12.004 .

Cheng J., Tianxiang G., Zhenqing M., Takashi Y. 2011. Molecular phylogeny and evolution of Scomber (Teleostei: Scombridae) based on mitochondrial and nuclear DNA sequences. Chinese Journal of Oceanology and Limnology, 29, 297-310. DOI: 10.1007/s00343-011-0033-7.

Costa G., Freitas N., Dellinger T.H., MacKenzie K. 2007. Gill monogeneans of the chub mackerel, Scomber japonicus from Madeiran waters of the Atlantic Ocean, Portugal. Journal of Helminthology, 81, 33-38. DOI: 10.1017/S0022149X07207 333.

Costa G., Cavallero S., D’Amelio S., Paggi L., Garcia Santamaria M.T., Borges Perera C., João Santos M., Khadem M. 2011. Helminth parasites of the Atlantic chub mackerel, Scomber colias Gmelin, 1789 from Canary Islands, Central North Atlantic, with comments on their relations with other Atlantic regions. Acta Parasitologica, 56, 98-104. DOI: 10.2478/s11 686-011-0006-1.

Cremonte F., Sardella N.H. 1997. The parasito fauna of Scomber japonicus Houttuyn, 1782 (Pisces: Scombridae) in two zones of the Argentine Sea. Fisheries Research, 31, 1-9. DOI: 10.1016/S0165-7836(97)00024-6.

Cressey R., Cressey H.B. 1980. Parasitic copepods of mackerel and tuna-like fishes (Scombridae) of the world. Smithsonian Contributions to Zoology, 311, 1-186.

FAO 2011. FishStatJ: Universal software for fishery statistical time series. FAO Fisheries and Aquaculture Department, Statistics and Information Service.

Culurgioni J., Mele S., Merella P., Addis P., Figus V., Cau A., Karakulak F.S., Garippa G. 2014. Metazoan gill parasites of the Atlantic bluefin tuna Thunnus thynnus (Linnaeus) (Oste- ichthyes: Scombridae) from the Mediterranean and their possible use as biological tags. Folia parasitologica, (in press). DOI: $10.14411 / \mathrm{fp} .2014 .011$

Gargouri Ben Abdalah L., Elbohli S., Maamouri F. 2010. Digenean diversity in labrid fish from the Bay of Bizerte in Tunisia. Journal of Helminthology, 84, 27-33. DOI: 10.1051/parasite/2012192129.

Garibaldi L., Caddy J.F. 1998. Biogeographic characterization of Mediterranean and Black Seas faunal provinces using GIS procedures. Ocean and Coastal Management, 39, 211-227. DOI: 10.1016/S0964-5691(98)00008-8.

Gibson D.I., MacKenzie K., Cottle J. 1981. Halvorsenius exilis gen. et. sp. nov., a new didymozoid trematode from the mackerel Scomber scombrus L. Journal of Natural History, 15, 917-929. DOI: 10.1080/00222938100770681.

Gibson D.I., Bray R.A., Harris E.A (Compilers) 2005. Host- Parasite Database of the Natural History Museum. London. World Wide Web electronic publication. Available from: http://www. nhm.ac.uk/research-curation/research/projects/host-parasites/ database/.

Hayward C.J., Perera K.M.L., Rohde K. 1998. Assemblages of ectoparasites of a pelagic fish, slimy mackerel (Scomber australasicus), from south-eastern Australia. International Journal for Parasitology, 28, 263-273. DOI: 10.1016/S00207519(97)00186-0.

Ichihara A., Kamegai S., Machida M. 1968. Parasitic helminths of mackerel, Pneumatophorus japonicus (Houttuyn). Research Bulletin of the Meguro Parasitological Museum, 2, 45-60.

Kabata Z. 1979. Parasitic copepoda of British fishes. Ray Society Publs, 152: 1-468. The Ray Society, London.

Lester R.J.G., Barnes A., Habib G. 1985. Parasites of skipjack tuna, Katsuwonus pelamis: fishery implications. Fishery Bulletin, $83,343-356$

Manca B., Burca M., Giorgetti A., Coatanoan C., Garcia M.J., Iona A. 2004. Physical and biochemical averaged vertical profiles in the Mediterranean regions: an important tool to trace the climatology of water masses and to validate incoming data from operational oceanography. Journal of Marine Systems, 48, 83-116. DOI: 10.1016/j.jmarsys.2003.11.025.

Marzoug D., Boutiba Z., Gibson D.I., Pérez-del-Olmo A., Kostadinova A. 2012. Descriptions of digeneans from Sardina pilchardus (Walbaum) (Clupeidae) off the Algerian coast of the western Mediterranean, with a complete list of its helminth parasites. Systematic Parasitology, 81, 169-86. DOI: 10.1007/s11230011-9335-6.

Mele S., Macías D., Gómez M.J., Garippa G., Alemany F., Merella P. 2012. Metazoan parasites on the gills of the skipjack tuna Katsuwonus pelamis (Osteichthyes: Scombridae) from the Alboran Sea (western Mediterranean Sea). Diseases of Aquatic Organisms, 97, 219-225. DOI: 10.3354/dao02421.

NikolaevaV.M. 1980. On the Black Sea Didymozoidae, species composition, morphology and distribution. Ekologiya Morya, 2, $81-85$.

Oksanen J. 2011. Multivariate analysis of ecological communities in R: Vegan tutorial. World wide web electronic publication. Available from: http://cc.oulu.fi/ jarioksa/opetus/metodi/vegantutor.pdf, accessed 23 January 2013.

Öktener A., Trilles J.P. 2009. Four parasitic copepods on marine fish (Teleostei and Chondrichthyes) from Turkey. Acta Adriatica, $50,121-128$

Oliva M.E., Valdivia I.M., Costa G., Freitas N., Pinheiro De Carvalho M.A., Sanchez Z.L., Luque J.L. 2008. What can metazoan parasites reveal about the taxonomy of Scomber japonicus Houttuyn in the coast of South America and Madeira Islands. Journal of Fish Biology, 72, 545-554. DOI: 10.1111/j.1095-8649.2007.01725.x. 
Pascual S., Abollo E., Azevedo C. 2006. Host-parasite interaction of a muscle-infecting didymozoid in the Atlantic mackerel Scomber scombrus L. ICES Journal of Marine Science, 63, 169-175. DOI: 10.1016/j.icesjms.2005.08.010.

Perera K.M.L. 1994. Light and electron microscopic study of the pathology of a species of didymozoid (Trematoda, Digenea) infecting the gill arches of Scomber australasicus (Teleostei, Scombridae). Diseases of Aquatic Organisms, 18, 119-127. DOI: $10.3354 /$ dao02421.

R Development Core Team 2012. R: A language and environment for statistical computing. R Foundation for Statistical Computing. Vienna, Austria.

Reiczigel J., Rózsa L. 2005. Quantitative Parasitology 3.0. Budapest. Distributed by the authors.

Robinson A.R., Wayne G.L., Theocharis A., Lascaratos A. 2001. Mediterranean Sea Circulation. Encyclopedia of Ocean Sciences, 3, 1689-1705. DOI: 10.1006/rwos.2001.0376.

Rohde K. 1989. Kuhnia sprostonae Price, 1961 and K. scombercolias Nasir and Fuentes Zambrano, 1983 (Monogenea: Mazocraeidae) and their microhabitats on the gills of Scomber spp. (Teleostei: Scombridae), and geographical distribution of gill Monogenea of Scomber spp. Systematic Parasitology, 14, 93-100. DOI: 10.1007/BF00016903.

Rohde K., Watson N. 1985. Morphology and geographical variation of Pseudokuhnia minor n. g., n. comb. (Monogenea: Polyopisthocotylea). International Journal for Parasitology, 15, 557-567. DOI: 10.1016/0020-7519(85)90053-0.

Rohde K, Hayward CJ. 2000. Oceanic barriers as indicated by scombrid fishes and their parasites. International Journal for
Parasitology, 30, 579-583. DOI: 10.1016/S0020-7519(00) 00023-0.

Romuk-Wodoracki D. 1988. Parasitic fauna of Atlantic mackerel (Scomber scombrus L.) from the fishing grounds of Cape Hatteras. Acta Ichthyologica et Piscatoria, 13, 49-60.

Shukhgalter O.A. 2004. Parasite fauna of the chub mackerel (Scombridae: Scomber japonicus Houttuyn, 1782) in the central eastern Atlantic Ocean (the Atlantic coast of the North Africa and the Azores banks). Parasitologiya, 38, 160-170 (in Russian).

Solonchenko A. I., Bodyanitski V.A. 1968. Parasite fauna of Scomber colias from the Atlantic Ocean near the South western coast of Africa. "Naukova Dumka", Biology of seas. No. 14. Parasites of marine animals. Kiev. pp. 90-95.

Somdal O., Schram T.A. 1992. Ectoparasites on northeast Atlantic mackerel (Scomber scombrus L.) from western and North Sea stocks. Sarsia, 77, 20-31.

Velasco E.V., Del Arbol J., Baro J., Sobrino I. 2011. Age and growth of the Spanish chub mackerel Scomber colias off southern Spain: a comparison between samples from the NE Atlantic and the SW Mediterranean. Revista de Biología Marina y Oceanografia, 46, 27-34.

Verneau O., Du Preez L., Badets M. 2009. Lessons from parasitic flatworms about evolution and historical biogeography of their vertebrate hosts. Comptes Rendus Biologies, 332, 149-158. DOI: 10.1016/j.crvi.2008.08.019.

Yamaguti S. 1970. Digenetic trematodes of Hawaiian fishes. Keigaku Publishing Co. Tokyo.

Received: May 27, 2013

Revised: August 3, 2013

Accepted for publication: December 11, 2013 